u.s. Department of | Energy Efficiency \&

בN Jicy Renewable Energy

Challenges and Successes on the Path toward a Solar-Powered Community
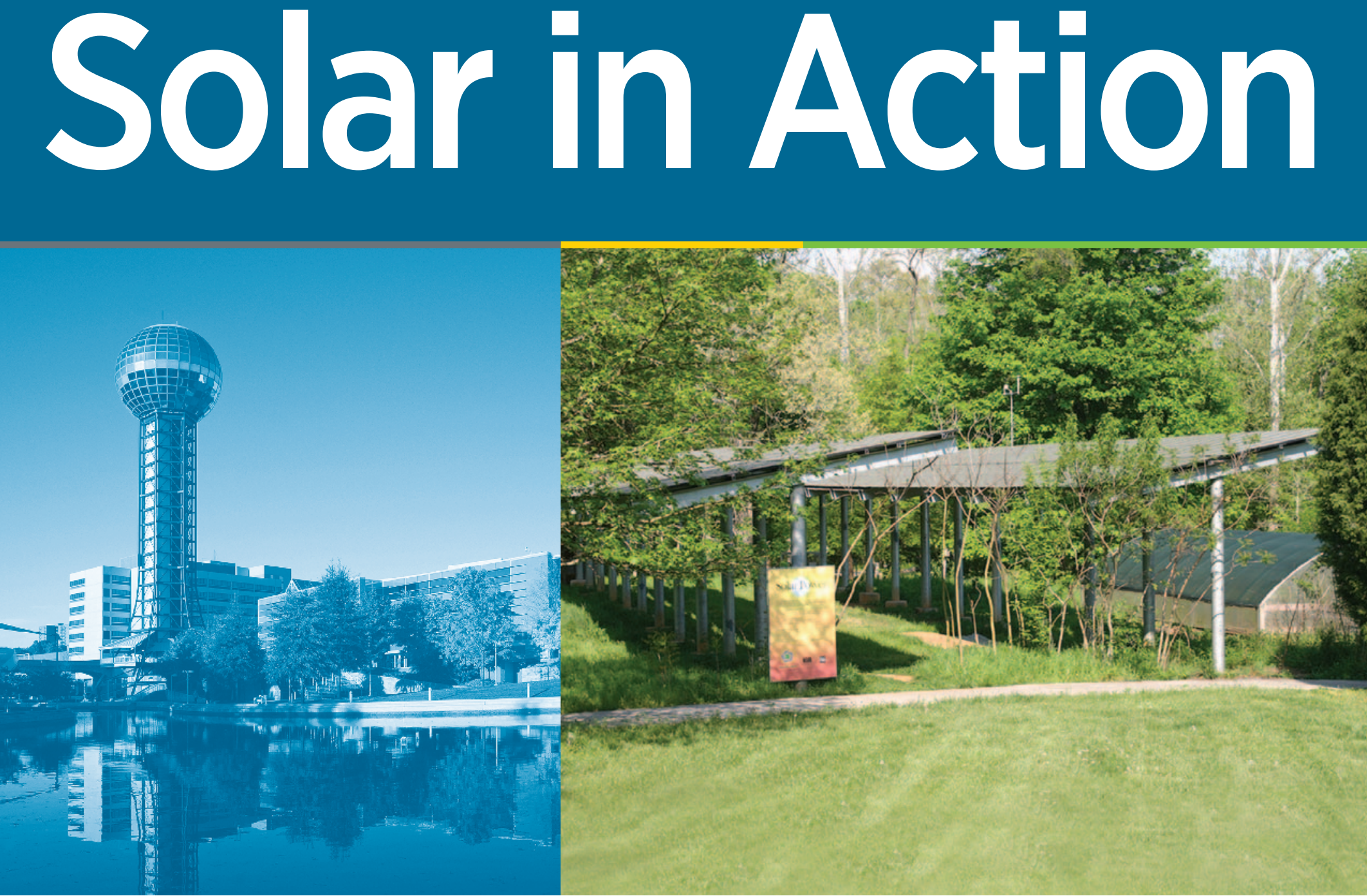

SOLAR AMERICA CITIES

Part of the Solar America Communities program

\title{
Knoxville, Tennessee
}

Includes case studies on:

- Educating the Community Through Consumer Workshops

- Demonstrating Photovoltaic Technologies

- Engaging Existing Industry to Promote Market Expansion

- Allowing Solar Energy Systems in Historic Districts 


\section{Knoxville's Starting Point}

The Solar America Cities program provided funding to enhance a solar energy exhibit at the ljams Nature Center, near downtown Knoxville. Photo from City of Knoxville, NREL/PIX 18694

Cover photos from iStock/12660092, Knoxville Sunsphere
About the U.S. Department of Energy's Solar America Communities program:

The U.S. Department of Energy (DOE) designated 13 Solar America Cities in 2007 and an additional 12 cities in 2008 to develop comprehensive approaches to urban solar energy use that can serve as a model for cities around the nation. DOE recognized that cities, as centers of population and electricity loads, have an important role to play in accelerating solar energy adoption. As a result of widespread success in the 25 Solar America Cities, DOE expanded the program in 2010 by launching a national outreach effort, the Solar America Communities Outreach Partnership. As the Solar America Cities program evolved to include this new outreach effort, the program was renamed Solar America Communities to reflect DOE's commitment to supporting solar initiatives in all types of local jurisdictions, including cities and counties. Visit Solar America Communities online at www.solaramericacommunities.energy.gov.
The City of Knoxville was designated by the U.S. Department of Energy (DOE) on March 28, 2008 as a Solar America City. Unlike some other Solar America Cities, Knoxville in many ways started from scratch. At the time of the award, the city had minimal experience with solar energy. There were only two medium-sized photovoltaic (PV) systems in the city-a 15-kilowatt (kW) system at ljams Nature Center and an 8-kW system on the Mellow Mushroom restaurant-and only a handful of residential systems.

Working with its partners, and with technical assistance from the DOE, the Knoxville Solar America Cities team planned to identify the highest priority barriers impeding expansion of the solar market in Knoxville.

Program partners recognized that the Knoxville community generally didn't consider solar technology "ready for primetime." Lack of public understanding and awareness perpetuated a lack of market demand. Industry pioneers struggled to overcome funding issues and locate customers for their products. Conventional electricity, produced at coal- and nuclear-fired plants, was very inexpensive in Knoxville. Potential solar installations therefore required a lengthy horizon for energy savings to offset costs. Those citizens who did commit to solar investments often faced restrictive design guidelines as well as building officials inexperienced with solar arrays.

\section{Building Partnerships and Setting Goals}

In 2007, Knoxville launched its Energy and Sustainability Initiative by establishing a task force of representatives from 15 local institutions to help guide the city's development of a strategic energy and environmental plan. Task force members and city staff immediately began working toward building energy efficiency and renewable energy capacity.

Knoxville's designation as a Solar America City capitalized on that strong and timely confluence of priorities between the city and its major partner organizations. Each individual organization had its own interests in increasing market penetration of solar technology, and together, the group saw the potential for creating a "solar hot spot" in the Southeast. Partners of Knoxville's Solar America Cities program were as follows: 
- Tennessee Valley Authority (TVA) (a federally owned public power company)

- Knoxville Utilities Board

- Southern Alliance for Clean Energy (SACE)

- Tennessee Department of Economic and Community Development

- Pellissippi State Community College

- Knox Heritage, Inc. (a local nonprofit organization that promotes the preservation of historic buildings)

- Knoxville Area Transit

- Public Building Authority (PBA)

- Ijams Nature Center

- Oak Ridge National Laboratory

- Florida Solar Energy Center

The partnership, known as "Solar Knoxville," planned to use the Solar America Cities program to build on the city's Energy and Sustainability Initiative by:

- Installing two highly visible solar systems in strategic locations - one on the new Leadership in Energy and Environmental Design (LEED)-certified downtown transit station and the other on a historic home that was being rehabilitated to LEED Gold Certification standards

- Educating the Knoxville community about solar technology through outreach efforts, including "Solar 101" workshops, a clearinghouse website, and an annual Solar Fair; these programs aimed to educate residents and business owners, as well as property assessors and architects, among others

\section{Installed Capacity \\ Knoxville}

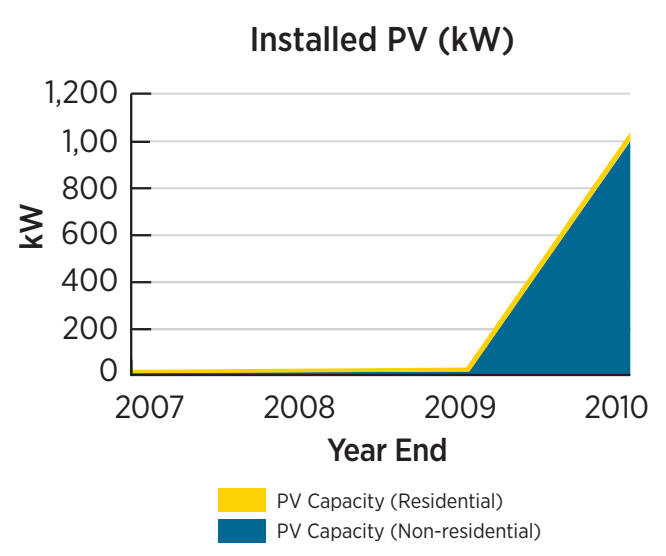

Installed PV capacity increase from December 31, 2007, to December 31, 2010

- Promoting cost-effective use of solar hot water technology by showcasing it in an affordable housing project and developing a solar hot water market barrier assessment to help identify opportunities for market growth

- Reaching a school-aged audience by enhancing an interpretive exhibit of an existing solar installation at a local nature preserve and outdoor educational facility

- Conducting workforce development training programs for solar installers, inspectors, and code officials to facilitate quality installations, safe and timely inspections, and approvals

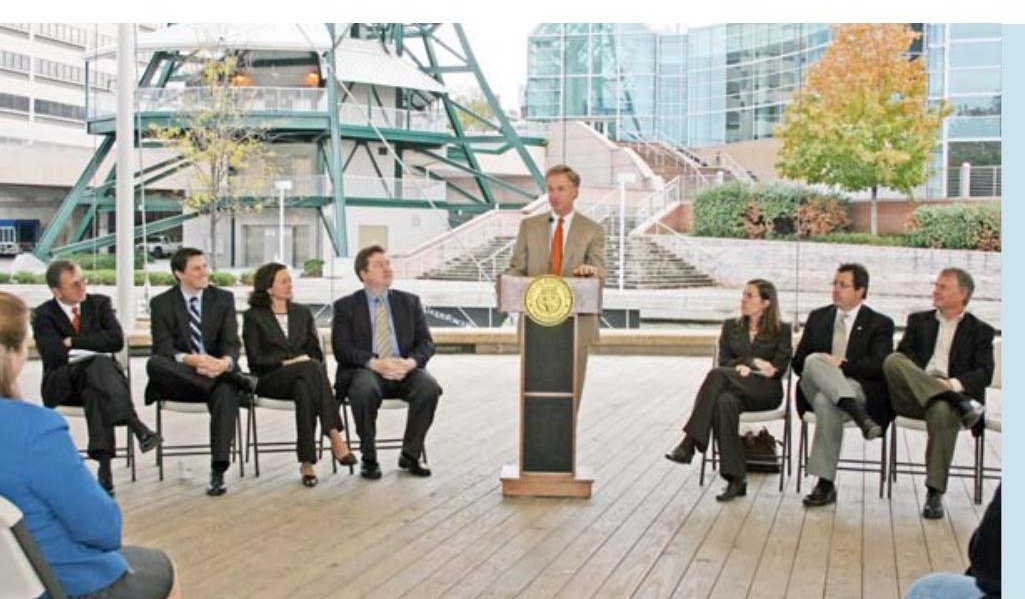

Knoxville's then-Mayor Bill Haslam speaks at the Solar America Cities kickoff event in Knoxville. Photo from Gil Hough, NREL/PIX 18693 
- Program leaders and technical assistance providers from Oak Ridge National Laboratory helped select, through a competitive bid process, Sustainable Future to install a 4.68-kW PV system at the new downtown Transit Center, which opened in August 2010.

- In part because of Solar Knoxville's efforts, the City of Knoxville's Department of Policy and Communications received the Tennessee Municipal League's 2009 Excellence in Green Leadership Award.

\section{Case Studies: Successes and Challenges}

\section{Educating the Community Through Consumer Workshops}

One of the biggest obstacles to the growth of the solar market in Knoxville is that most citizens lack information about, and experience with, solar technology. To help educate its residents, the city hosted a series of free public solar energy workshops. Participants learned about different solar technologies, various incentives for purchasing solar systems, and how to find qualified installers, such as those certified by the North American Board of Certified Energy Practitioners (NABCEP).

Each workshop focused on different segments of the population (e.g., residents, businesses, utilities), and was tailored for the appropriate audience. Workshops have been taught by faculty at Pellissippi State Community College (PSCC) and by SACE. The workshops and related consumer information are promoted through the city's Solar Knoxville Clearinghouse, available online at www.solarknoxville.org.

Lessons Learned: One challenge was trying to find experts in the field while remaining neutral and not promoting a particular company. Solar Knoxville benefited from having SACE and Oak Ridge National Laboratory available to present. Otherwise, quality presenters may have been hard to provide.

Solar Knoxville learned how to best tailor the workshops' content, organization, and logistics to the targeted audiences. Business audiences specifically required a high degree of detail presented efficiently. Therefore, Solar Knoxville held two business workshops, which looked very different. The first was just an overview, but the second attempted to connect businesses with the specific programs and people that could be pursued for follow-up after the workshops.

It was critical to engage all stakeholders in the publicity and content development of the workshops. The Knoxville
Chamber, Knox Heritage, and the Department of Community Development helped market Solar Knoxville to targeted audiences. Had these organizations, along with the Knoxville Utilities Board and TVA, not been such close partners, it might have been more difficult for Solar Knoxville to keep the incentive information presented in the workshops as current as possible.

Overall, there was significant support from the public sector and other entities, including the Knoxville Utilities Board and the Knoxville Chamber. Attendance dropped off as the Solar 101 workshops continued, but that was likely due to the saturation of the interested public sector.

\section{Demonstrating Photovoltaic Technologies}

The Solar Knoxville program helped fund the installation of solar arrays on Knoxville's downtown transit center and on a historic home. The 4.68-kW installation at the newly constructed downtown transit center-Knoxville's first municipally owned PV system - was fully funded by the TVA through a cost-share agreement. The system was designed to demonstrate the practical and attractive use of PV to the public. The PV array, which is positioned to receive maximum sunlight, is visible from multiple angles on the ground. The PV system design features transparent and semitransparent panels and an aesthetically pleasing mounting structure to enhance the overall aesthetic qualities of the transit center. An exhibit is located in the transit center waiting area to educate transit users about solar energy, the building's PV system, and LEED characteristics of the building.

The Solar Knoxville program also provided funding for the installation of an innovative solar PV system on the roof of a historic home that was rehabilitated to LEED Certified standards. Working with a local historic preservation group, Knox Heritage, program leaders used the project to encourage the use of solar technologies on historic buildings. The 2.72-kW PV array showcases Unisolar thin-film solar panels flush-mounted in between the seams of a standing seam metal roof that blend with the look and historic nature of the home, and demonstrates that solar and historic preservation can be compatible. Also, the project was leveraged to help revise local historic design codes to better accommodate solar technologies.

Lessons Learned: The PBA managed city-owned buildings and oversaw the construction of the transit center and the solar array, but had not worked with solar technology before. Although PBA leaders remained highly engaged and 
committed to the solar installation, their lack of experience slowed the design and planning process.

Oak Ridge National Laboratory staff facilitated PBA's rapid learning of critical information and provided assistance in reviewing the work of installation contractors. This expert assistance was key to ensuring the quality of this installation, and the experience left PBA well-prepared to independently manage additional solar projects.

A larger, and perhaps related, challenge was balancing design and installation timelines with the approval steps associated with federal funding of the project - namely, the National Environmental Policy Act. A major lesson from this experience is that project timelines must allow substantial room for delays in meeting federal requirements.

Like the transit center project, the installation of solar on the Knox Heritage Green Home faced similar delays, but its primary challenge was designing a solar array that did not distract from the historic character of the home. The project team worked extensively with historic zoning commissioners to identify key design concerns. The collaboration was instrumental to the project's success, because the historic zoning commission had to approve the final design.

Another challenge was following the proper planning process. Initially, the project team issued a request for proposals that emphasized cost but didn't make clear the strong need for innovative, progressive-market design. Contractor bids, therefore, did not live up to expectations. In response, the team dramatically revised the request for proposals. The second request focused extensively on the need for proposed designs to address the historic design considerations and reflect market innovation. A cost limit was provided, but there was not as much preference for low-cost proposals. Responses were much stronger in the second round - the winning firm came in under budget, but more importantly used innovative, low-visual impact technologies that were new to the local market. Although the project team considers the project a design success, it is worth noting an important trade-off: working with new technologies slowed the installation process, as contractors had to familiarize themselves with a new product.

\section{Engaging Existing Industry to Promote Market Expansion}

At the start of the Solar Knoxville program, Knoxville's solar market was very small and unorganized. The city engaged and networked with local installers and area solar technology companies to better understand market barriers and craft practical solutions to those problems. The city, serving as a hub of communications among installation companies, facilitated partnerships, assisted the industry in lobbying for changes at the state level, and instilled a level of accountability among installers. Since the program began, the solar market in Knoxville has transformed from a small, fringe industry to one with multiple, large professional companies and a significant presence in the community's commercial sector.

Lessons Learned: Barriers included a lack of public awareness of the benefits of solar energy and process of installing such systems; a lingering negative perception of installers in past decades who installed multiple systems and left town soon thereafter, leaving orphaned systems throughout the community; a lack of experienced and knowledgeable solar contractors; a lack of visibility of installed solar systems; a lack of financial incentives; and zoning and permitting restrictions.

As the market grew, it became more difficult for the Solar Knoxville program to engage equally with numerous small, new companies. Ultimately, this challenge signaled the growing maturity of the Knoxville market, but it required the Solar Knoxville program to constantly readjust its strategy for how to engage effectively with industry leaders. Although Solar Knoxville shared a close relationship with installers, it was critical to the credibility of the program that it maintained strong "company-neutrality," so as not to give one company in the network an edge over another.

One of the most challenging points of conversation surrounding Solar Knoxville's effort to strengthen the market involved the decision of whether to require NABCEP certification for installers seeking city projects or incentives. Particularly in the early stages of the program, there was strong technical incentive to promote NABCEP, but requiring certification risked excluding a substantial number of new players. To deal with the dilemma between promoting market quality or quantity, the city gave preference to NABCEP-certified installers for early projects, then required NABCEPcertification in later projects.

\section{Allowing Solar Energy Systems in Historic Districts}

Before revision, the language of the Knoxville/Knox County Historic Zoning Building Guidelines reflected a concern that the visual appearance of solar technologies would destroy the character of a historic home and mandated that solar technologies not be installed where visible from rights of way.

The Solar Knoxville program presented an overview of modern solar technologies to the historic zoning commission; 
metropolitan planning commission; and city inspection, permitting, and code department, and proposed new guidelines that preserved the intent to protect historic character and integrity yet better accommodated solar technologies. After a final review by the zoning commission and consensus by historic neighborhood associations, the new guidelines were formally adopted.

Lessons Learned: The historic zoning department, historic community, and neighborhoods supported these changes. Although the support was stronger than expected, there were many more procedural and legal steps to revising the codes than initially anticipated. Proposed guidelines were continuously revised to comply with legal language requirements.

Also, due to a relatively small and tight-knit community of historic preservation stakeholders, there was significant pressure to accommodate the concerns of specific individuals. Although the historic zoning commission had final say on whether the guidelines would be adopted, commissioners requested that Solar Knoxville incorporate the opinions of neighborhood constituents.

\section{Top Takeaways}

- Engaging and educating the public early and often is helpful to incorporating solar into municipal operations.

- Maintaining a positive relationship with local utilities and energy providers is essential.

- TVA's Generation Partners Program, which credits excess PV generation at the local utility rate $+\$ 0.12$ /kilowatt-hour for systems up to $200 \mathrm{~kW}$, was essential to the increased use of solar systems, but the program is subject to funding availability.

- The Solar Knoxville website is critical to educating the Knoxville community about solar energy and helping citizens better navigate the process of purchasing and installing solar technologies. The site's clearinghouse style provides comprehensive, consistent, and accessible information related to the program and solar technologies.

\section{Next Steps}

- The city's sustainability coordinator (who led Knoxville's Solar America Cities efforts) will be funded through 2012 with the American Recovery and Reinvestment Act Energy Efficiency and Conservation Block Grant. The block grant funding also will be used to catalyze the installation of a large, highly visible PV array atop the Knoxville Convention Center, a municipally owned facility.

- The city's Energy and Sustainability Initiative will work to ensure that technical policies, such as building codes, permitting, and design guidelines, accommodate solar technologies.

- SACE will continue consumer outreach and market development efforts.

- It is a testament to the success of the program that as Solar Knoxville comes to an end, the local market demonstrates increasing self-sufficiency and potential to thrive in the long term. Local businesses were critical to forming the Tennessee Solar Industries Association, which is working to lobby for stronger solar policies at the state level. Their organization, along with support from the state government and TVA, will remain critical to continued increases in solar technology deployment.

\section{Additional Resources}

- Solar Knoxville: www.solarknoxville.org

- Solar Knoxville on YouTube: www.youtube.com/user/Solarknoxville\#p/u

- TVA Generation Partners Program: www.tva.gov/greenpowerswitch/partners/index.htm

- Southern Alliance for Clean Energy (SACE): www.cleanenergy.org

- Tennessee Solar Institute (TSI): http://solar.tennessee.edu

- Tennessee Solar Energy Association (TSEA): www.tnsolarenergy.org 
